\title{
The baseline assessment of Grade 1 learners' literacy skills in a socio-economically disadvantaged school setting
}

\begin{tabular}{|c|c|}
\hline \multicolumn{2}{|c|}{$\begin{array}{l}\text { Authors: } \\
\text { Zelda Wildschut }{ }^{1} \\
\text { Trevor Moodley }{ }^{2} \\
\text { Shelley Aronstam }{ }^{1}\end{array}$} \\
\hline \multicolumn{2}{|c|}{$\begin{array}{l}\text { Affiliations: } \\
{ }^{1} \text { Education and Social } \\
\text { Sciences, Cape Peninsula } \\
\text { University of Technology, } \\
\text { South Africa }\end{array}$} \\
\hline \multicolumn{2}{|c|}{$\begin{array}{l}\text { 2Department of Educational } \\
\text { Psychology, University of the } \\
\text { Western Cape, South Africa }\end{array}$} \\
\hline \multicolumn{2}{|c|}{$\begin{array}{l}\text { Corresponding author: } \\
\text { Zelda Wildschut, } \\
\text { wildschutzm@telkomsa.net }\end{array}$} \\
\hline \multicolumn{2}{|c|}{$\begin{array}{l}\text { Dates: } \\
\text { Received: } 30 \text { July } 2015 \\
\text { Accepted: } 04 \text { May } 2016 \\
\text { Published: } 12 \text { Aug. } 2016\end{array}$} \\
\hline \multicolumn{2}{|c|}{$\begin{array}{l}\text { How to cite this article: } \\
\text { Wildschut, Z., Moodley, T. \& } \\
\text { Aronstam, S., 2016, 'The } \\
\text { baseline assessment of Grade } \\
1 \text { learners' literacy skills in a } \\
\text { socio-economically } \\
\text { disadvantaged school } \\
\text { setting', South African Journal } \\
\text { of Childhood Education 6(1), } \\
\text { a340. http://dx.doi. } \\
\text { org/10.4102/sajce.v6i1.340 }\end{array}$} \\
\hline \multicolumn{2}{|c|}{$\begin{array}{l}\text { Copyright: } \\
\text { (C) 2016. The Authors. } \\
\text { Licensee: AOSIS. This work } \\
\text { is licensed under the } \\
\text { Creative Commons } \\
\text { Attribution License. }\end{array}$} \\
\hline \multicolumn{2}{|l|}{ Read online: } \\
\hline 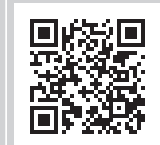 & $\begin{array}{l}\text { Scan this QR } \\
\text { code with your } \\
\text { smart phone or } \\
\text { mobile device } \\
\text { to read online. }\end{array}$ \\
\hline
\end{tabular}

Research has revealed that the academic performances of learners in South Africa are below the required level. The Western Cape Education Department (WCED) launched the literacy and numeracy strategy 2006-2016 in response to the low literacy and numeracy levels. In addition, the WCED introduced the Grade 1 baseline assessment in 2006, as part of the literacy and numeracy strategy. The purpose of this study was to observe the implementation of the Grade 1 literacy baseline assessment programme of the WCED. This study aimed to determine what literacy barriers, if any, the learners were experiencing and to recommend literacy support strategies, in order to inform teaching practices. Purposive sampling was used for the selection of a Grade 1 class, with English as the language of learning and teaching. Thirty-seven Grade 1 learners participated in the study. A mixed-methods research design was used to collect both quantitative and qualitative data. The data collection strategies employed included documentary analysis, by examining participants' school admission forms to provide biographical information as well as their written baseline assessment scripts. The baseline assessment process was also observed as it was being conducted. The findings suggest that some of the learners experienced literacy barriers in terms of receptive and expressive language, perceptual skills and fine motor development. The data were summarised, and the information was used to describe the literacy barriers in terms of the biographical variables and to recommend learning support strategies for literacy development.

\section{Introduction}

The academic performances of South African learners have been a cause for great concern over the past few years. A study undertaken by the South African National Department of Education found that only $28 \%$ of Grade 6 learners in South African schools performed the required literacy level (South Africa Department of Education 2005:77), while the Joint Education Trust Report indicates that the systemic evaluation literacy results of South African Grade 3 learners in 2007 were at an unacceptable level of only 36\% (Khumalo 2008:1). In addition, the study of the Annual National Assessment results indicated that the average percentage scores in Home Language dropped from 59\% at Grade 1 level to $28 \%$ at Grade 6 level in 2011 and from 58\% to 43\% in 2012 (South Africa Department of Education 2012:2-3). In response to the low literacy and numeracy levels of learners in schools, the Western Cape Education Department (WCED) introduced the Grade 1 baseline assessment literacy, numeracy and life skills programme, in 2006, as part of the literacy and numeracy strategy 2006-2016 (WCED 2007:Foreword). Another compounding factor is that many Grade 1 learners have not attended reception year (the first year at primary school before Grade 1) classes; therefore, many of these learners have not acquired the concepts, skills and strategies taught in these classes (WCED 2007:Foreword).

The early identification of at-risk children at preschool and the provision of appropriate intervention and support can substantially affect their future scholastic progress. The purpose of this study was to examine the Grade 1 baseline assessment literacy programme to identify what literacy barriers the learners experienced, in order to improve the literacy skills of the Grade 1 learners.

\section{Literacy development}

Literacy is the ability to read, write, speak, listen and think. These abilities are interrelated and should be developed in an integrated manner to ensure effective literacy development. Language plays an important role in literacy development. Instructions in phonemic awareness, phonics, oral reading, vocabulary, reading comprehension and writing contribute to literacy development (Dednam 2005:119-120; Diehl 2011:186). Center (2005:19) postulates that an interactive approach 
to literacy may support the development of the learners' listening skills and spoken language competence. Reciting of rhymes and words with alliteration may assist with the development of the learners' listening skills (Dednam 2005:371).

The stages that children go through in their early development of speech and language are important for the establishment of their interpersonal communication skills. Early grammatical utterances enable young children to interact with others, to get things done and to comment on a state of affairs in the environment (Whitehead 2011:52, 56, 61). Bruce and Spratt $(2011: 16,18)$ postulate that the way the brain works to co-ordinate hearing, vision and movement is crucial in literacy development. Bruce and Spratt add that the way in which the eyes, hands and fingers move together is vital for the development of reading and writing.

Justice and Pullen (2003:99) state that emergent literacy is highly influenced by the social and cultural contexts in which children are reared. According to Irwin et al. (2012:20-21) emergent literacy skills play an important role in literacy development and include alphabet knowledge, concepts about print, phonological awareness and expressive vocabulary. Learners need to recognise the letters of the alphabet in order to recognise words. Concept about print is the ability to differentiate between letters, numbers, words and pictures and can be taught while reading a simple book to the learners with large, clear print. Phonological awareness and sensitivity refers to the ability to distinguish between the sounds of spoken words and to recognise rhyming words as well as the ability to segment words into syllables. Listening and oral comprehension activities will assist to develop learners' receptive language and expressive language as well as their reasoning.

Levey (2011:4) states that receptive language enables learners to remember details of stories and to understand words and sentences in stories. Research conducted by Florit et al. (2009:947) found that receptive language skills are powerful predictors of listening comprehension. Byrnes and Wasik (2009:39) explain that expressive language is the ability of the learners to express themselves in meaningful ways. It involves the sequencing of words when constructing sentences in conversations and stories and the ability of the speaker to speak about certain topics when communicating with others. Byrnes and Wasik add that spoken language competence connects language abilities to social competence.

Book-handling is also an important skill and includes the ability to hold a book properly and the knowledge that reading progresses from left to right (Center 2005:16; Irwin et al. 2012:20-21). Emergent literacy skills are acquired by most children incidentally and gradually during the years preceding formal literacy instruction. Young children begin to read by recognising logos on fast-food restaurants, shops in the environment and commonly used household products. (Justice \& Pullen 2003:99-100; Tompkins 2010:114).

\section{Factors that may impact literacy development}

The following factors may impact literacy development.

\section{Socio-economic factors}

Children from varying socio-economic status levels differ significantly in the opportunities to engage in literacy-related activities in the home (Heath et al. 2014:2). The amount of money, time and energy that parents spend on educational resources are considered investments that have the potential to enhance children's cognitive and language skills. Education in low socio-economic communities of South Africa is hampered because of a non-stimulating environment, insecurity, language deficiency and poor orientation towards school (Hartas 2011:894; Prinsloo 2005:28). Irwin et al. (2012:21-22) state that learners from low socio-economic communities often enter school with limited knowledge of vocabulary.

The findings of research conducted by Parsons and Schoon (2011:212) suggest that children with poor language development grow up in a family environment characterised by reduced levels of material and human resources. In addition, the findings suggest that parents of poor readers may be less likely to have an extended education, but they can be encouraged to be interested in their child's education, as well as their own, with family learning programmes. A study conducted by Hartas (2011:907) found that the educational qualifications of parents are important aspects in the literacy skills of learners. Learners with educated parents were on average 6 months ahead with literacy compared to their peers whose parents did not have any educational qualifications.

\section{The class teacher}

An understanding relationship between the teacher and learners as well as a stimulating classroom environment will also enhance literacy development (Landsberg 2005:69-70). The physical literacy environment refers to the design, arrangements and display of various literature material. It includes the availability of a classroom library with a variety of genres, dramatic play area, block centre, the science table as well as a print-rich classroom. A print-rich classroom includes posters, signs and teacher and learner writing samples that are related to the classroom theme (Guo et al. 2012:310)

\section{The home language of the learners}

Many learners who are taught through the medium of English, which is not their home language, are limited in their English proficiency. This might result in emotional and social difficulties, because they may not be able to use language adequately and may find it difficult to understand what others are saying (Cameron 2003:107; Dednam 2011:129-131; Nel 2005:150). Prior, Bavin and Ong (2011:14) emphasise that children who begin school with poorly developed language are seriously at risk of long-term struggles in school. Well-developed communication and 
word skills are fundamental to a good start in the early stages of school.

\section{Grade R education}

Early childhood education provides opportunities to young children to master different skills through active participation and can play a crucial role in addressing issues that will prevent learners at risk from developing learning barriers (Harty \& Alant 2011:90). Early childhood education can play an important role in developing the school readiness of learners.

According to Prior et al. (2011:4), school readiness is important because children's capabilities at school entry correlate significantly with later skills. Quirk et al. (2011:80) postulate that a growing body of research categorises the elements of school readiness into the following readiness areas: cognitive, social-emotional and behavioural as well as physical. They add that children who have a broad base of school readiness experiences have been found to acquire complex skills more rapidly than those who do not have them.

Cognitive readiness has been found to be a predictor of later academic achievement. Children with low emotional regulation abilities are less productive and have difficulty learning in the classroom environment. Physical readiness refers to the general health and well-being of a learner at school entry and the physical environment a child may be exposed to during the preschool years. A child's physical readiness for school, strongly affects a learner's cognitive, social-emotional and behavioural readiness (Quirk et al. 2011:81).

The South African Department of Education (2011:20-21) states that the Grade $\mathrm{R}$ daily programme provides opportunities for learners to develop perceptual-motor skills, which may promote the development of their gross and fine motor co-ordination. Grade R education may assist learners to become au fait with classroom routines and to focus on educational activities for reasonable periods, which may support learners to develop the required literacy skills at the end of Grade R (South Africa Department of Education 2011:20-21).

Perceptual skills are important for the development of reading skills. Perception involves a sequence of interrelated events that mutually influence each other (Sekuler \& Blake 2002:15). Learners gain knowledge by extracting information from the environment when their senses are stimulated (Forgus \& Melamed 1976:1-3). Joubert (2013:370-371) encourages teachers to guide learners to use their senses optimally to ensure that the information that was extracted from the environment is interpreted correctly. Dednam (2005:370-371) postulates that visual discrimination enables learners to differentiate between words that almost look alike and auditory discrimination assists learners to distinguish between similar sounds such as ' $b$ ' and ' $d$ ', ' $m$ ' and ' $n$ ' and words like 'brown' and 'drown'. Grové and Hauptfleish
(1981:6) state that auditory perception may be developed by involving learners in listening games.

Perceptual-motor skills refer to movement activities and are important for the development of book-handling and writing skills. The gross motor muscles develop in the arms and legs and develop ahead of fine motor muscles. Activities that involve body movement will improve motor development and control and will assist learners to develop the correct posture to support written activities (Laszlo \& Bairstow 1985:5, 173). Fine motor co-ordination involves finer and more complex movements that are executed by using the hands, fingers and wrist muscles (Joubert 2013:186-189; Mwamwenda 2004:45).

\section{Gender}

Both biological and environmental factors play a role in gender differences. Children's perceptions of themselves are determined by the expectations, treatment and interactions with the world outside the school (Mwamwenda 2004:261). According to Browne (1996:169, 172-173), research has found that emergent literacy skills' development may be influenced by gender differences. Boys seem to be better at listening and speaking activities while girls are better with emergent reading and writing activities. Research conducted on a comparison of school readiness scores by de Lemos (2008:88) and on gender differences by Bellow et al. (2010:251) found that girls enter school with stronger emergent reading skills than boys.

According to Bellow et al. (2010:241), research suggests that gender differences in reading skills are influenced by environmental or cultural and/or societal causes. For example, teachers may hold higher expectations for female students during reading activities. Interest and motivation may also contribute to reading deficits in male students. Although boys prefer non-fiction and informational material that provides fact over fictional materials, fictional reading is typically used during elementary school reading instruction. Browne (1969:173) states that research has also revealed that boys and girls hold very different attitudes towards writing. Girls often enjoy imaginative and personal writing, while boys feel less competent at writing and prefer factual and technical writing. According to Browne (1996:173), these views are not genetic but are created by the institutional and societal examples that children see around them.

\section{The chronological age of the learner}

Grové and Hauptfleisch (1981:9-10) postulate that school maturity refers to a biological growing process in the development of children when certain aptitudes appear before the start of formal schooling. This involves physical and mental security and is a biological process that cannot be hastened. They explain that maturation is the stage when children are ready for formal instruction in reading, writing and mathematics and is usually reached by children at about the age of six years. However, Grové and Hauptfleisch add that intellectual maturity is not a guarantee for success at 
school, because children who are intellectually mature may not be school ready if they do not feel secure.

According to de Lemos (2008:73-74), children all over the world start school at about the age of 5 or 6 years. Children are seen as being ready to take on more responsible tasks and to be capable of more formal learning at this age. De Lemos explains that most children learn to read between the ages of 5-7 and adds that while the ability to read is dependent on a number of underlying skills that are linked with development, the acquisition of reading is in most cases not achieved without formal instruction in reading. Thus, both development and learning are necessary in achieving reading skills. Crone and Whitehurst (1999:608-609) found that older children outperformed their younger classmates in emergent literacy skills at the end of kindergarten.

\section{Assessment}

The importance of assessment in schools has increased because of educational accountability (Wright 2008:1). Assessment is an integral part of learning and teaching and a daily component of classroom activities. Teachers use a variety of procedures to monitor the progress of learners in order to prepare appropriate lesson plans that will cater for the different abilities of the learners. Furthermore, they use a variety of assessment tools to assess the progress of their learners. Teachers should observe the learners as they participate in activities and record their performances on checklists in order to monitor their progress (Tompkins 2010:28-29).

\section{Baseline assessment}

Baseline assessments may include cognitive, affective and behavioural aspects and is conducted at the beginning of a new grade to determine what learners know. The different purposes of a baseline assessment are to identify the level of learners in order to inform planning, to identify learners with special needs, to compare the results with learners' later progress and to compare the progress of a group of learners with another group of the same age or grade (Tymms 1999:14, 20). The criteria for baseline assessment should include clear objectives, accurate and reliable recording of information and the information obtained must be of practical value for future planning. The protection of learners' and parents' rights and evidence of learners' achievements are also important aspects when conducting baseline assessments (Wolfendale 1995:42-43).

\section{Research question}

The main research question in this study was the following.

How can the Grade 1 literacy baseline assessment results be used to address literacy barriers among Grade 1 learners?

The following research sub-questions assisted in the aim to recommend learning support strategies for literacy:
1. What do the Grade 1 learners' literacy baseline assessment performances indicate about their emergent literacy skills?

2. What learning support strategies can be recommended to address the literacy barriers (if any) identified by the baseline assessment?

\section{Methodology Research design}

A concurrent mixed-methods case study approach was used to investigate the emergent literacy skills of a group of Grade 1 learners during the implementation of the WCED Grade 1 baseline assessment literacy programme. The study included the collection and analysis of both quantitative and qualitative data (Creswell \& Clark 2011:66).

\section{Participants}

Prior to the commencement of the study, ethical protocols were followed and included written permission and informed consent from the WCED research directorate, the school where the study was conducted, the Grade 1 teacher who conducted the literacy baseline assessment programme and the parents of the learner participants. Thirty-seven Grade 1 learners and their class teacher who conducted the literacy baseline assessment participated in the study. The participants were selected from a primary school, situated in a low socioeconomic community, on the Cape Flats in the Cape Town Metropole of the Western Cape. Many learners come from homes where there is a lack of exposure to reading material and resources such as television sets or where there is not enough money to buy electricity for the television set to be operational. We selected the Grade 1 class, with English as the language of learning and teaching (LOLT), because of the diverse nature of the learners. The mother tongue of many of these learners are Xhosa, Afrikaans or both Afrikaans and English. The study sample of learner participants consisted of 20 female participants and 13 male participants. The age range of the learners was between 5.5 and 7.5 years. The second sample just included the teacher of the Grade 1 class who had conducted the baseline assessment that was observed.

\section{Baseline assessment instrument}

The WCED Grade 1 literacy baseline assessment programme (WCED 2007:Foreword) is a written document that explains how the Grade 1 baseline assessment activities should be conducted within the first 3 weeks of the school year. It consists of the following sections: An introduction, Section A (recording sheets), Section B (exemplar work schedules for the baseline assessment programme) and Section $\mathrm{C}$ (alternative version of the baseline assessment programme). The introduction explains how the teachers must plan for the implementation of the activities. The recording sheets are checklists to record the performances of the learners. The exemplar work schedule provides teachers with an outline of activities to be implemented and the skills, knowledge and 
attitudes that must be assessed. The exemplar lesson plans are included in the work schedule section, which is a 10-day programme. The lesson plans explain how the activities can be implemented as well as the focus for assessment (WCED 2007:68).

The WCED 2007 baseline literacy assessment instrument is a standard recording document. It is a checklist to record what learners can or cannot demonstrate in terms of the expected literacy skills and knowledge that learners should have acquired by the end of Grade R (WCED 2007:1). Therefore, it provides the baseline assessment criteria of the different literacy categories that were assessed.

The WCED literacy baseline assessment checklist was adapted for this study in the following manner: The listening and speaking components of the WCED checklist were combined in the observation checklist because both components were simultaneously assessed during the same assessment activities. The category labels 'reading and viewing' and 'writing' were, respectively, changed to 'emergent reading' and 'emergent writing' in order to align the concepts with the recent changes in the South African school curriculum and, in this instance, specifically with regard to the Grade $\mathrm{R}$ Home Language Curriculum Assessments and Policy Statement (CAPS) concepts (South Africa Department of Education 2011:31-35). In addition, the 'thinking and reasoning' as well as the 'language structure and use' categories of the WCED checklist were combined with the 'listening and speaking' as well as the 'emergent reading' categories in the adapted checklist. The rationale for combining those categories is that the 'thinking and reasoning' and 'language structure and use' categories have been integrated with the listening and speaking, emergent reading and emergent writing categories of the CAPS Home Language programme (South Africa Department of Education 2011:8). Therefore, learners' emergent literacy competence was evaluated in terms of three categories: listening and speaking, emergent reading and emergent writing. The activities included in each category are listed below.

The listening and speaking category of the baseline assessment assessed the abilities of the learners in seven activities; namely: (1) listen attentively to stories for enjoyment, (2) respond to questions, (3) follow instructions, (4) participate in games and songs, (5) match colours, (6) share information and (7) to use language appropriately.

The emergent reading category involved eight activities; namely, (1) recognise words in the environment, (2) holding a book and turning pages appropriately, (3) interpret pictures, (4) recognise the sound symbols of the alphabet, (5) to complete a puzzle, (6) to recall, (7) to identify similarities and differences in a picture as well as (8) their abilities to complete a figure-ground activity.

The emergent writing category involved six activities; namely, (1) to manipulate their writing tools, (2) use letters to represent writing, (3) directionality, (4) the ability to write on a page, (5) use colour in their drawings and (6) to convey amessage about their drawings.

\section{Data collection strategies}

Multi-method data collection strategies were used to collect the data for this study. This study involved documentary analysis, field observations, as well as an interview.

\section{Documentary analysis}

The learners' admission files provided information regarding the learners' biographical profiles such as gender, home languages, Grade R attendance and their chronological ages. The biographical information was used to statistically describe the learner sample. Participants' written assessment scripts provided information regarding the written literacy baseline assessment activities. In addition, they assisted in identifying literacy barrier patterns, because they complemented and, in instances, confirmed data collected from the observation process. The performances of the learners were also analysed in terms of participants' biographical variables; namely, gender, language, Grade $\mathrm{R}$ attendance and chronological age.

Participants' baseline assessment scripts were examined and the findings were recorded in the literacy assessment checklist by indicating the barriers that the learners experienced with an ' $X$ '. Learners' performances in the literacy baseline assessment were judged on the bases of what the individual could or could not do successfully. Therefore, evaluation of learner performances was binary in nature. The frequencies of literacy barriers for each emergent literacy category were organised in a table in terms of gender, home language, age and Grade $\mathrm{R}$ attendance. This enabled the identification and statistical description of the different performance and barrier patterns that emerged.

\section{Field observations}

Most of the concepts of the baseline activities were repeated every day during the baseline assessment. Four learners were observed at a time to examine their skills during the literacy baseline assessment activities, in order to ensure manageability of the observation process. The learners wore colour-coded name tags on their school jackets, shirts or dresses in order to facilitate the identification of the learners who were observed. The learners were observed at their tables during the paper-based activities and in smaller groups in the reading corner during role-play reading. Name tags were also pasted on the tables that facilitated the identification of the learners who were observed during the paper-based activities. The observation of learners focused on cognitive, affective and behavioural aspects and enabled the recording of their reactions to the various assessment activities that were administered. Detailed field notes were taken during the class activities, which facilitated the recording of verbal as well as non-verbal cues of the participants. The data collected from the field observations were organised in the 
literacy assessment checklist. The literacy assessment checklist facilitated the interpretation and analysis of both quantitative and qualitative data.

Therefore, data were analysed in terms of the notes made during observations, the examination of participants' assessment answer scripts and clarification with the teacher to ensure the reliability of the observations of the learners' responses.

\section{Findings and discussion}

\section{What do the Grade 1 learners' literacy baseline assessment performances indicate about their emergent literacy skills?}

\section{Barriers for the sample as a whole}

For the sample as a whole, $28 \%$ of the total number of performances (693) was unsatisfactory, thereby indicating the percentage of barriers for all performances during the baseline assessment literacy programme. The literacy category where the highest percentage of barriers was experienced was emergent reading (38\%), out of 264 performances, and the category where the lowest percentage of barriers was experienced was emergent writing (20\%), out of 198 performances. The listening and speaking category had $25 \%$ of barriers for all performances (231) in that category.

Participants' overall performances in the literacy baseline assessment activities suggested that barriers were experienced in about a third (28\%) of the performances. Their receptive and expressive language skills were important in order for them to successfully participate in the listening and speaking categories because listening and oral comprehension activities assist to develop learners' receptive and expressive language as well as their reasoning (Center 2005:16). Their perceptual skills were important for the successful completion of the activities in the emergent reading categories. For example, visual discrimination enables learners to differentiate between words that almost look alike and auditory discrimination assists learners to distinguish between sounds such as ' $b$ ' and ' $d$ ', ' $m$ ' and ' $n$ ' and words like 'brown' and 'drown' Dednam (2005:370-371). Perceptualmotor skills were important during the emergent reading and writing activities. For example, the book-handling activity (emergent reading) required fine motor co-ordination that involves movements that are executed by using the hands, fingers and wrist muscles (Joubert 2013:186).

In all the activities of the listening and speaking category, there were learners who did not satisfactorily demonstrate those skills. The skill in which the highest number of learners performed unsatisfactorily was the ability to share information, whereas the skill in which the highest number of learners performed satisfactorily was the ability to listen attentively to stories.

The skill in which the highest number of learners performed unsatisfactorily in the emergent reading category was the ability to recall, and the skill in which the highest number of learners performed satisfactorily was the ability to recognise words in the environment (logos and the learners' own names).

The emergent writing activities indicated that the highest number of learners performed unsatisfactorily in the activity that assessed their abilities to use different colours in drawings, and the highest number of learners performed satisfactorily in the activities that assessed their abilities to write the letters of the alphabet, to write from left to right and their abilities to write on a page.

The findings suggest that the learners who were unable to listen attentively to stories, answer questions on the stories, follow instructions in order to participate effectively in action songs and games, match colours and identify the sounds of the letters of the alphabet may have experienced barriers with receptive language. Receptive language is the ability to understand the spoken language and involves the learners' listening skills. Receptive language skills are also powerful predictors of listening comprehension (Florit et al. 2009:947).

The learners who were not confident to respond to questions, share information during class discussions, to use language appropriately and use a drawing to convey a message may have expressive language barriers. Expressive language is the ability of the learners to express themselves in meaningful ways. It involves the sequencing of words when constructing sentences in conversations and stories and the ability of the speaker to speak about certain topics when communicating with others (Byrnes \& Wasik 2009:39). The stages that children go through in their early development of speech and language are important for the establishment of their interpersonal communication skills (Whitehead 2011:52).

The inabilities of some of the learners to match colours according to instructions, recognise words in the environment, identify sounds and symbols, interpret pictures, complete puzzles, to recall, identify differences in pictures, identify a background picture, use letters to represent writing, write on a page and use colours appropriately indicate that the learners possibly experienced perceptual barriers. Perception involves a sequence of interrelated events that mutually influence each other (Sekuler \& Blake 2002:15). Learners gain knowledge by extracting information from the environment when their senses are stimulated. Learning, memory and thinking play an important role in perceptual development and enable the learner to extract more information from the environment (Forgus \& Melamed 1976:1-3).

Barriers related to perceptual-motor development possibly account for the reason why some of the learners were unable to identify the symbols of the letters of the alphabet, according to the initial sounds of words, and write appropriately on a page. Perceptual-motor skills refer to movement activities that involve the perceptual skills of the learners. Accurate movement and control over the muscles are necessary for all intellectual functions and involve the gross and fine motor 
skills of the learners (Grové \& Hauptfleisch 1981:26). The gross and fine motor skills are the most important skills in the perceptual-motor development of the learners and include the development of hand-eye co-ordination and body image (Joubert 2013:187; Mwamwenda 2004:45).

\section{Literacy performances in terms of gender}

Participants' performances in terms of gender revealed that among male participants the percentage of barriers for the entire assessment (all performances by male participants) was $31 \%$. In terms of the three literacy categories, the percentage barriers for male performances were $22 \%$ in the listening and speaking category, $42 \%$ in the emergent reading category and $26 \%$ in the emergent writing category. Therefore, male performances were the least satisfactory in the emergent reading category. The percentage female barriers was $27 \%$ for the entire assessment, $26 \%$ in the listening and speaking category, $35 \%$ in emergent reading category and $17 \%$ in the emergent writing category. The male students experienced fewer barriers in the listening and speaking category than the female students, while the female students experienced fewer barriers in the emergent reading and emergent writing categories than the male students.

Research suggests that development of emergent literacy skills may be influenced by gender differences. Boys seem to be better at listening and speaking activities while girls are better with emergent reading and writing activities and enter school with stronger emergent reading skills (Bellow et al. 2010:251; de Lemos 2008:88; Mwamwenda 2004:261). This study's findings support Mwamwenda's (2004) and Browne's (1996) contentions, as well as the research findings of de Lemos and of Bellow et al. because more female students (26\%) experienced barriers in listening and speaking activities than male students (22\%). Male participants in this study experienced more barriers in both the emergent reading and emergent writing activities than female participants.

\section{Literacy performances in terms of home language}

The learners whose home language was English experienced the following percentage barriers $27 \%$ for the entire assessment, $17 \%$ in listening and speaking, 38\% in emergent reading and $24 \%$ in emergent writing. The percentage barriers for Xhosa home language speakers were $36 \%$ for the entire assessment, $48 \%$ in the listening and speaking category, $41 \%$ in the emergent reading and $17 \%$ in the emergent writing. Afrikaans home language speakers experienced $24 \%$ barriers for the entire assessment, 14\% barriers in listening and speaking, $40 \%$ barriers in emergent reading and $13 \%$ barriers in emergent writing. Of the learners whose home language was both English and Afrikaans, 21\% experienced barriers for the entire assessment, $21 \%$ experienced barriers in listening and speaking, 25\% in emergent reading and $17 \%$ in emergent writing.

This study's findings partially indicate that learners whose mother tongue was not the same as the LOLT experienced overall more barriers than those whose mother tongue
(English) was also the LOLT. Language barriers may have played a major role in some learners not seemingly understanding the instructions of the teacher during most of the literacy baseline assessment activities. Well-developed communication and word skills are fundamental to a good start in the early stages of school (Prior et al. 2011:14).

\section{Literacy performances in terms of attendance or non-attendance}

Among the learners who attended Grade R, 28\% experienced barriers for the entire assessment, $26 \%$ experienced barriers in the listening and speaking category, 38\% in emergent reading and $18 \%$ in emergent writing. The percentage barriers of those learners who did not attend Grade $\mathrm{R}$ was $29 \%$ for the entire assessment, $20 \%$ in listening and speaking category, 38\% in emergent reading and 29\% in emergent writing. The performances of all these learners, those who attended Grade $\mathrm{R}$ and those who did not attend, were the least satisfactory in the emergent reading category. The learners who did not attend Grade $\mathrm{R}$ experienced fewer barriers in the listening and speaking category than those who attended Grade R, while those who attended Grade R experienced fewer barriers in the emergent writing category. The performances of the learners who attended Grade $\mathrm{R}$ and those who did not were the same in the emergent reading category.

Overall, more barriers (29\%) were indicated for participants who had not attended Grade R compared to $28 \%$ for those who did. Additionally, an analysis of participants' performances indicated that there was a higher frequency of barriers for the group who had not attended Grade $\mathrm{R}$ than those who did in the emergent writing category ( $29 \%$ vs. $18 \%$ ). Grade R education may assist learners to focus on educational activities for reasonable periods, which may support learners to develop the required literacy skills at the end of Grade $\mathrm{R}$ (South Africa Department of Education 2011:20-21). The frequency of barriers for emergent reading activities was the same for both groups (38\%). However, the participants who did not attend Grade R experienced fewer barriers in the listening and speaking category than those who attended Grade R (20\% vs. 26\%).

\section{Literacy performances in terms of chronological age}

The following percentage barriers were experienced by the 5.5- to 6-year-old learners: $25 \%$ for the entire assessment, $21 \%$ in the listening and speaking category, 35\% in emergent reading and $19 \%$ in emergent writing. The 6.5 - to 7.5 -year-old learners experienced the following percentage barriers: $32 \%$ for the entire assessment, $30 \%$ in the listening and speaking category, $42 \%$ in emergent reading and $22 \%$ barriers in emergent writing. The performances of all these learners, in both age categories, were the least satisfactory in emergent reading, compared to listening and speaking and emergent writing.

More learners in the 6.5- to 7.5-year-old age group (32\%) experienced barriers in the emergent literacy activities 
compared to the learners in the 5.5- to 6-year-old age group $(25 \%)$. The learners in the 6.5- to 7.5-year-old age group also experienced more barriers than the learners in the 5.5- to 6-year-old age group in the listening and speaking category (30\% vs. $21 \%)$, emergent reading category ( $42 \%$ vs. $35 \%)$ and in the emergent writing category (22\% vs. $19 \%)$. Grade $\mathrm{R}$ attendance (school readiness) could have played a role in the younger learners outperforming the older learners in their listening and speaking and emergent reading skills because $89 \%$ of the learners in the 5.5- to 6-year-old age group attended Grade $\mathrm{R}$ versus $67 \%$ of the learners in the six-and-a half to seven-and-a half year old group. This finding once more emphasises the importance of Grade $\mathrm{R}$ education in building the foundational skills required for learning.

\section{What learning support strategies can be recommended to address the literacy barriers (if any) identified by the baseline assessment instrument?}

The abilities to read, write, listen and think are interrelated and should be developed in an integrated manner to ensure effective literacy development (Diehl 2011:186).

\section{Strategies to improve receptive and expressive language skills}

Receptive language skills are important for the successful completion of all the activities in the listening and speaking as well as the emergent reading and writing categories. Expressive language skills are required to respond to questions, share information, to interpret pictures (emergent reading category) and to convey a message using a drawing (emergent writing category). The learners' listening skills, vocabulary and their abilities to participate in class discussions may be developed by means of an interactive approach to literacy (Center 2005:19), because it could facilitate the creation of an effective classroom environment.

The reading of stories with large print and big pictures could capture the attention of the learners and may improve the listening comprehension skills of the learners and may help the learners to connect speech and print (Center 2005:19-21; Irwin et al. 2012:21). Furthermore, the involvement of the learners in the discussion of pictures of the stories could also improve the participation of learners in class discussions (Center 2005:19-21). A stimulating classroom environment will support literacy development (Landsberg 2005:70).

Support at school and support at home are important for the development of the receptive and expressive language of the learners (Hartas 2011:894). The parents of the learners who experienced barriers during the literacy assessment in this study should be encouraged to support their children with literacy activities at home. However, many parents in low socio-economic communities feel inadequate to help their children because of their own unsuccessful school experiences, cultural differences or their limited ability to read and write in English. The involvement of parents in family learning programmes may encourage them to be interested in their child's education, as well as their own educational development (Parsons \& Schoon 2011:212).

\section{Strategies to improve perceptual skills}

Visual perception development activities should be included in the literacy programme in order to support the learners to identify, organise and interpret observed objects (Dednam 2005:370). The teacher should guide learners to use their senses optimally in order to ensure that the information that was extracted from the environment is interpreted correctly (Joubert 2013:140). Visual discrimination development may enable the learners to identify different words in the environment (Dednam 2005:370).

The inclusion of listening games in the education programme may promote the development of auditory perception, which may improve the abilities of the learners to carry out instructions and to convey a message (Grové \& Hauptfleish 1981:6). Reciting of rhymes will assist learners in developing the auditory memory of the learners, because it provides opportunities for them to listen to and identify rhyming words. Furthermore, learners should also be encouraged to listen to words with alliteration and to repeat the words and identify the beginning sounds of the words they have heard (Dednam 2005:371).

\section{Strategies to improve perceptual-motor skills}

The teacher should involve learners in activities that require them to use their gross motor muscles such as throwing a ball into a basket, hitting a suspended ball with a bat and balancing by standing on the preferred leg. Movement activities should also be included such as walking forward on a balancing beam and jumping up and down as well as crawling over and under apparatus. Gross motor skills will assist learners to develop the correct posture to support written activities (Laszlo \& Bairstow 1985:5, 173).

The involvement of learners in activities that require them to manipulate objects which involves the use of their hands, fingers and wrists may nurture the development of their fine motor co-ordination skills. The development of the fine motor muscles is important because fine motor co-ordination may improve the book-handling skills of the learners. In addition, it will assist learners with the correct pencil grip and the correct movement when writing the letters of the alphabet and may support the effective use of a pair of scissors (Joubert 2013:186; Laszlo \& Bairstow 1985:173).

Improvement of the hand-eye co-ordination of the learners may assist them to copy written work from the chalkboard, improve their writing skills and could improve their reading ability (Grové \& Hauptfleisch 1981, 6). The learners should be involved in activities that require them to use their hands and their eyes such as catching a ball, drawing patterns and tracing, because it may assist the development of their hand-eye co-ordination skills.

The inclusion of activities that involve the use of different body parts, identifying body parts on dolls and movements 
in different directions can promote the development of the awareness of the body image of the learners. The ability to differentiate between different directions may support the correct use of a page when writing and will address directionality, because it may enable learners to write from left to write and from the top to the bottom (Joubert 2013:187).

\section{Conclusion}

This study found that the WCED literacy baseline assessment instrument provides a valuable means of identifying literacy barriers of learners at the beginning of Grade 1. The results of the listening and speaking activities assisted in identifying possible barriers with receptive language, expressive language and perceptual skills. The results of the emergent reading activities assisted in identifying possible barriers with perceptual skills, receptive and expressive language barriers as well as barriers with motor development. The results of the emergent writing activities assisted in identifying possible barriers with perceptual-motor development, perceptual skills and expressive language barriers. Participants' performances seemed to be influenced more by their attendance or non-attendance of Grade R rather than their chronological age. In fact, the younger age cohort fared better than the older age cohort in the baseline assessment, probably because a higher percentage of younger learners had attended Grade R.

\section{Acknowledgements Competing interests}

The authors declare that they have no financial or personal relationships which may have inappropriately influenced them in writing this article.

\section{Authors' contributions}

Z.W. was the study leader. T.M. assisted with the conceptualisation of the study and the analysis of data. S.A. assisted with conceptualisation of the study and the literature review.

\section{References}

Bellow, J.L., Skinner, C.H., Fearrington, J.Y. \& Sorrell, C.Y., 2010, 'Gender differences in early literacy: Analysis of kindergarten through fifth grade dynamic indicators of basic early literacy skills probes', School Psychology Review 39(2), 240-257.

Browne, A., 1996, Developing language and literacy 3-8, Paul Chapman, London.

Bruce, T. \& Spratt, J., 2011, Essentials of literacy from 0-7: A whole-child approach to communication, language and literacy, Sage, London.

Byrnes, J.P. \& Wasik, B.A., 2009, Language and literacy development: What educator need to know, Guilford, New York.

Cameron, L., 2003, 'Challenges for ELT from expansion in teaching children', ELT Journal 57(2), 105-122. http://dx.doi.org/10.1093/elt/57.2.105

Center, Y., 2005, Beginning reading: A balanced approach to literacy instruction during the first three years at school, Continuum, London.

Creswell, J.W. \& Clarck, V.L.P., 2011, Designing and conducting mixed methods research, 2nd edn., Sage, Thousand Oaks, CA.

Crone, D.A. \& Whitehurst, G.J., 1999, 'Age and schooling effects on emergent literacy' Journal of Educational Psychology 91(4), 604-614. http://dx.doi.org/10.1037/ 0022-0663.91.4.604

Dednam, A., 2005, 'First language problems', in E. Landsberg, D. Krüger \& N. Nel (eds.), Addressing barriers to learning: A South African perspective, pp. 119-144, Van Schaik, Pretoria.
Dednam, A., 2011, 'First language difficulties in spoken language', in E. Landsberg, D. Krüger \& E. Swart (eds.), Addressing barriers to learning: A South African perspective, 2nd edn., pp. 126-141, Van Schaik, Pretoria.

de Lemos, M.M., 2008, 'Assessing development and readiness for school across different cultures and language groups', Australian Journal of learning difficulties 13(2), 73-98. http://dx.doi.org/10.1080/19404150802380597

Diehl, S., 2011, 'Supporting the development of literacy skills from infancy through school age', in S. Levey \& S. Polirstok (eds.), Language development: Understanding language diversity in the classroom, pp. 185-208, Sage, CA.

Florit, E., Roch, M., Altoè, G.S. \& Levorato, M.C., 2009, 'Listening comprehension in pre-schoolers: The role of memory', British Journal of Development Psychology 27, 935-951. http://dx.doi.org/10.1348/026151008X397189

Forgus, R.H. \& Melamed, L.E., 1976, Perception a cognitive stage approach, McGrawHill, USA.

Grové, M.C. \& Hauptfleisch, H.M., 1981, Perceptual developmental: A guide, De JagerHaum, Pretoria.

Guo, Y., Justice, L.M., Kaderavek, J.N. \& McGinty, A., 2012, 'The literacy environment of preschool classrooms: Contribution to children's growth', Journal of Research in Reading 35(3), 308-327. http://dx.doi.org/10.1111/j.1467-9817.2010.01467.x

Hartas, D., 2011, 'Families' social background matter: Socio-economic factors, home learning and young children's language, literacy and social outcomes', British Educational Research Journal 37(6), 893-914. http://dx.doi.org/10.1080/014119 26.2010.506945

Harty, M. \& Alant, E., 2011, 'Early childhood development and intervention', in E. Landsberg, D. Krüger \& E. Swart (eds.), Addressing barriers to learning: A South African perspective, 2nd edn., pp. 87-105, Van Schaik, Pretoria.

Heath, S.M., Bishop, D.V.M., Bloor, E., Boyle, G.L., Fletcher, J., Hogben, J.H., et al., 2014, 'A spotlight on pre-school: The influence of family factors on children's early literacy skills', Open Access 9(4), 1-15.

Irwin, J.R., Moore, D.L., Tornator, L.A. \& Fowler, A., 2012, 'Expanding on early literacy: Promoting emerging language and literacy during story time', The Journal for the Association for Library Service to Children, 20-29, Summer.

Joubert, I., 2013, Literacy in the Foundation Phase, Van Schaik, Pretoria.

Justice, L.M. \& Pullen, P.C., 2003, 'Promising interventions for promoting emergent literacy skills: Three evidence-based approaches', Topics in Early Childhood Special Education 23(3), 99-113. http://dx.doi.org/10.1177/02711214030230030101

Khumalo, G., 2008, 'Foundation Phase learners show improvement', viewed 23 May 2012, from http://www.skillsportal.co.za/page/education

Landsberg, E., 2005, 'Learning support', in E. Landsberg, D. Krüger \& N. Nel (eds.), Addressing barriers to learning: A South African perspective, pp. 61-77, Van Schaik, Pretoria.

Laszlo, J.I. \& Bairstow, P.J., 1985, Perceptual-motor behaviour: Developmental assessment and therapy, Mackays, Liverpool.

Levey, S., 2011, 'An introduction to language and learning', in S. Levey \& S. Polirstok (eds.), Language development: Understanding language diversity in the classroom, pp. 1-16, Sage, CA.

Mwamwenda, T.S., 2004, Education psychology: An African perspective, Heinemann, Sandton.

Nel, N., 2005, 'Second language difficulties in a South African context', in E. Landsberg, D. Krüger \& N. Nel (eds.), Addressing barriers to learning: A South African perspective, pp. 149-168, Van Schaik, Pretoria.

Parsons, S. \& Schoon, I., 2011, 'Long-term outcomes for children with early language problems', Children and Society 25, 202-214. http://dx.doi.org/10.1111/ j.1099-0860.2009.00274.x

Prinsloo, E., 2005, 'Socio-economic barriers in contemporary society', in E. Landsberg, D. Krüger \& N. Nel (eds.), Addressing barriers to learning: A South African perspective, pp. 27-42, Van Schaik, Pretoria.

Prior, M., Bavin, E. \& Ong, B., 2011, 'Predictors of school readiness in five-to-six-yearold children from an Australian longitudinal community sample', Education Psychology 31(1), 3-16. http://dx.doi.org/10.1080/01443410.2010.541048

Quirk, M., Furlong, M., Lilles, E., Felix, E. \& Chin, J., 2011, 'Preliminary development of a kindergarten school readiness assessment of Latino students', Journal of Applied School Psychology 27, 77-102. http://dx.doi.org/10.1080/15377903.2010.540518

Sekuler, R. \& Blake, R., 2002, Perception, 4th edn., McGraw-Hill, Boston, MA.

South Africa Department of Education, 2005, Intermediate Phase Systemic Evaluation Report, Government Printer, Pretoria.

South Africa Department of Education, 2011, Curriculum and Assessment Policy Statement: Foundation Phase English Home Language, Government Printer, Pretoria.

South Africa Department of Education, 2012, Report on the annual national assessments of 2012: Grades 1 to 6 \& 9, Government Printer, Pretoria.

Tompkins, G.E., 2010, Literacy for the 21st century: A balanced approach, 5th edn., Pearson, Boston, MA.

Tymms, P., 1999, Baseline assessment and monitoring in primary schools, David Fulton, London.

Western Cape Education Department (WCED), 2007, Baseline assessment: Literacy, numeracy, life skills, Provincial Government of the Western Cape, Cape Town.

Whitehead, M., 2011, Language and literacy in the early years 0-7, Sage, London.

Wolfendale, S., 1995, Baseline assessment: A review of current practices, issues and strategies for effective implementation, Trentham, Staffordshire.

Wright, R., 2008, Educational assessment: Tests and measures in the age of accountability, Sage, Los Angeles, CA. 